\title{
IMPLIKASI PELATIHAN MENJAHIT DALAM MENUMBUHKAN KARAKTER WIRAUSAHA PESERTA DIDIK DI MASA PANDEMIC COVID-19
}

\author{
Erni Elisa Listiani, Ansori, Dinno Mulyono \\ Program Studi Pendidikan Masyarakat IKIP Siliwangi, Cimahi - Jawa Barat - Indonesia \\ erniels1stn@student.ikipsiliwangi.ac.id
}

Received: Mei, 2021; Accepted: Mei, 2021

\begin{abstract}
This research is motivated by the large number of unemployment rates in Indonesia caused by the COVID-19 pandemicc that threatens the health and economy of the community, especially among the learning citizens at the Mekar Sari Training and Training Institute. This research aims to make citizens learn to be able to improve their economy during the COVID-19 pandemicc through a sewing training program by fostering entrepreneurial character traits. The research method used is a qualitative approach using descriptive methods through interview techniques. The results of this study show that learning citizens are able to start independent businesses during the COVID-19 pandemicc. The conclusion of this study shows that the Course and Training Institute is a training place where students will get sewing skills according to their expertise. During the COVID-19 pandemicc, learning residents could improve their profession to open new businesses with the aim of increasing their family's economy because this sewing course and training institute is also one of the accesses that become an economic source for residents to learn to help their families and meet their daily needs.
\end{abstract}

Keywords: Course and Training Institution, Entrepreneurial Character, COVID-19 Pandemic

\begin{abstract}
Abstrak
Penelitian ini dilatar belakangi oleh banyaknya tingkat pengangguran di Indonesia yang disebabkan oleh adanya pandemic COVID-19 sehingga mengancam kesehatan dan perekonomian masyarakat terutama pada peserta didik yang ada di Lembaga Kursus dan Pelatihan Mekar Sari. Penelitian ini bertujuan agar peserta didik mampu meningkatkan perekonomiannya di masa pandemic COVID-19 ini melalui program pelatihan menjahit dengan menumbuhkan sifat karakter wirausaha. Metode penelitian yang digunakan adalah pendekatan kualitatif dengan menggunakan metode deskriptif melalui teknik wawancara. Hasil dari penelitian ini menunjukan bahwa peserta didik mampu untuk memulai usaha mandiri di masa pandemic COVID-19. Kesimpulan dari penelitian ini menunjukan bahwa Lembaga Kursus dan Pelatihan adalah tempat pelatihan dimana peserta didik akan mendapatkan keterampilan menjahit sesuai dengan keahlian yang mereka kuasai. Pada masa Pandemic COVID-19 ini peserta didik dapat meningkatkan profesinya untuk membuka usaha baru dengan tujuan menambah perekonomian keluarganya karena lembaga kursus dan pelatihan menjahit ini juga merupakan salah satu akses yang menjadi sumber perekonomian peserta didik untuk membantu keluarganya dan memenuhi kebutuhannya sehari-hari.
\end{abstract}

Kata Kunci : Lembaga Kursus dan Pelatihan, Karakter wirausaha, Pandemic COVID-19

How to Cite: Listiani, E.E. (2021). Implikasi Pelatihan Menjahit dalam Menumbuhkan Karakter Wirausaha Peserta Didik di Masa pandemi Covid-19. Comm-Edu (Community Education Journal), 4(2), 76-XX. 
64 Listiani, E.E. Implikasi Pelatihan Menjahit dalam Menumbuhkan Karakter Wirausaha

Peserta Didik di Masa pandemi Covid-19

\section{PENDAHULUAN}

Badan pusat statistik (BPS) merilis tingkat pengangguran terbuka (TPT) pada Agustus 2019 sebesar 5,28\% atau mencapai 7,05 juta orang. Angka pengangguran tersebut naik dibandingkan Agustus 2018 sebesar 7 juta orang atau turun secara persentase sebesar 5,34\%. Kepala BPS Suhariyanto menjelaskan, jumlah angkatan keja pada Agustus 2019 tercatat sebesar 197,92 juta orang, bertambah dibanding periode yang sama tahun lalu 194,78 juta. Adapun tingkat partisipasi kerja naik dari 66,67\% pada Agustus 2018 menjadi 67,49\%. Tingkat pengangguran terbuka tercatat turun (secara persentase) dari 5,34\% pada Agustus 2018 menjadi 5,28\% pada Agustus 2019, tingkat pengangguran tertinggi masih berasal dari lulusan SMK, tetapi trennya mulai menurun (Agustiyanti, 2019).

Virus Corona atau biasa disebut (COVID-19) bermula di Wuhan, China pada akhir Desember 2019 yang sudah menyebar di berbagai negara. Penyakit yang menular ini dapat menyebabkan infeksi pada saluran pernapasan yan mengakibatkan flu ringan ataupun berat, yang nantinya berpengaruh kepada daya tahan tubuh manusia, sehingga penyakit Virus Corona ini dapat mematikan seseorang yang tertular virus tersebut. Tingkat masyarakat yang terkena COVID-19 ini sangat tinggi (Idhom, 2020) . Pada masa pandemi seperti ini, hampir seluruh sektor di Indonesia terdampak, tidak hanya kesehatan, sektor ekonomi juga berdampak pada kehidupan sehari-hari akibat COVID-19. Pembatasan aktivitas masyarakat yang mengakibatkan aktivitas bisnis juga terhambat yang berimbas pada perekonomian. Oleh karena itu, untuk meminimalisir terjadinya penularan COVID-19 maka sebagian besar dari para perkerja di rumahkan atau WFH (Work From Home).

Di dalam pendidikan non-formal terdapat lembaga kursus dan pelatihan yang merupakan salah satu bentuk satuan pendidikan non-formal yang diselenggarakan bagi masyarakat yang memerlukan bekal pengetahuan, keterampilan, kecakapan hidup, dan sikap untuk mengembangkan diri, mengembangkan profesi, bekerja, dan usaha mandiri atau dapat melanjutkan pendidikan kejenjang yang lebih tinggi (Dewi, 2018). Lembaga kursus secara tidak langsung dapat membantu meningkatkan motivasi dan kemandirian seseorang dalam dunia pekerjaan ataupun mengembangkan kemampuan dalam berwirausaha.

Salah satu program pelatihan di LKP Mekar Sari yang cukup banyak diminati oleh masyarakat yaitu Program Menjahit. Hal ini terlihat dari data yang ditunjukkan oleh Pengelola LKP bahwa sekitar 70\% masyarakat lebih memilih pelatihan menjahit dari beberapa program pelatihan yang dilaksanakan di Kabupaten Bandung Barat. Program pelatihan menjahit ini merupakan salah satu pelatihan keterampilan kreatif. Pada dasarnya pelatihan kursus menjahit menekankan peserta didik dalam mengembangkan kemampuan atau potensi diri untuk diimplementasikan dalam kehidupan sehari-hari (Ahmad Husein, 2017).

Lembaga Kursus dan Pelatihan (LKP) Mekar Sari memiliki dua kelas yaitu kelas Reguler dan Kelas Program (gratis). Salah satu yang diteliti yaitu kelas reguler di mana dalam kelas reguler ini peserta didik melakukan pembayaran sampai lulus di level 1 dengan jangka waktu selama 3 bulan. Pada kelas reguler ini peserta didik bebas membuat rancangan atau desain pakaian sesuai dengan keinginan peserta didik seperti, kemeja, gamis, celana, rok, dan lain sebagainya.

Berdasarkan uraian di atas, dengan adanya program kursus menjahit di LKP Mekar Sari yang sudah sesuai standar dan telah menarik perhatian masyarakat untuk mengikuti pelatihan 
menjahit khususnya kaum perempuan yang tidak mempunyai kegiatan ataupun ingin meningkatkan keterampilan dalam menjahit untuk bisa mandiri agar dapat meningkatkan kesejahteraan hidupnya.

\section{METODE PENELITIAN}

Metode yang digunakan dalam penelitian ini yaitu pendekatan kualitatif dengan metode deskriptif. Teknik pengumpulan data yang digunakan yaitu metode wawancara, observasi, dan dokumentasi, tujuan utama dari teknik pengumpulan data ini agar didapatkan data lapangan yang mampu memberikan nilai tambah dalam menguatkan hasil analisis dari tiap teknik pengumpulan data yang berkaitan dengan sumber data kualitatif. Prosedur analisis data yang digunakan adalah pengumpulan data, penyajian data, reduksi data, dan pengambilan kesimpulan. Sedangkan untuk menguji validitas data, dilakukan dengan metode triangulasi. Adapun triangulasi dilakukan untuk menjelaskan keabsahan data dengan menggunakan sumber yang berbeda, dengan tujuan untuk menghindari adanya bias dalam hasil penelitian.

Objek penelitian pada saat pengumpulan data melalui wawancara dengan peserta didik pelatihan dan kursus menjahit sejumlah 4 orang, 1 orang tutor dan 1 orang pengelola di Lembaga Kursus dan Pelatihan Mekar Sari, Jl. Letkol G.A Manulang No. 63 RT. 02/ 04, Kecamatan Padalarang, Kab. Bandung Barat. Pemilihan responden tersebut didasarkan pada penentuan kapasitas dan pengalaman dalam bidang pelatihan menjahit. Terutama periode keterlibatan peserta didik, tutor dan pengelola dalam program tersebut, sehingga dapat memberikan jawaban yang lengkap dalam bidang pengelolaan keterampilan menjahit tersebut. Hal ini senada dengan pendapat dari Soegiyono (2018: 67) yang menyebutkan untuk penelitian kualitatif diperlukan keterwakilan dari sumber data yang dapat dipercaya.

\section{HASIL DAN PEMBAHASAN}

\section{Hasil \\ Pelaksanaan pelatihan menjahit dan meningkatkan penumbuhan karakter wirausaha pada peserta didik di LKP Mekar Sari di masa pandemic Covid-19}

Berdasarkan hasil wawancara bersama Pengelola LKP Mekar Sari, pelaksanaan pelatihan menjahit di masa pandemic Covid-19 memang sedikit terhambat, akan tetapi setelah berlakunya new normal dan adanya koordinasi dengan para pengelola LKP di Bandung Barat, sebagian dari LKP lain sudah mulai melaksanakan pelatihan kembali, maka pengelola di LKP Mekar Sari mulai melaksanakan kegiatan pelatihan seperti biasa setelah diliburkan selama 3 bulan. Dikarenakan LKP Mekar Sari terletak bersamaan dengan rumah pengelola, maka pengelola sangat memperhatikan protokol kesehatan, juga telah menyediakan tempat untuk mencuci tangan sebelum masuk ruangan. Serta menegaskan kepada tutor dan peserta didik agar selalu memakai masker ketika sedang melaksanakan pelatihan. Pengelola juga berperan sebagai pemberi materi mengenai menjahit setiap seminggu sekali kepada peserta didik.

Hasil wawancara kepada tutor kursus dan pelatihan menjahit di LKP Mekar Sari, diperoleh informasi bahwa kursus dan pelatihan menjahit di masa pandemic tetap dilaksanakan secara tatap muka dengan waktu yang tetap sama yaitu tiga kali pertemuan dalam satu minggu, yakni pada hari senin, rabu dan jum'at, mulainya dari jam 13.00 - 16.00. Dengan terhalangnya pandemic Covid-19 akan tetapi tidak mengurangi semangat tutor untuk terus melatih peserta didik dengan tetap melakukan praktik dari pada materi karena untuk kelas 
66 Listiani, E.E. Implikasi Pelatihan Menjahit dalam Menumbuhkan Karakter Wirausaha Peserta Didik di Masa pandemi Covid-19

reguler di pelatihan menjahit ini sudah mempunyai kurun waktu yang singkat yang telah ditentukan.

Berdasarkan pada hasil wawancara bersama 4 peserta didik dengan inisial AL, AS, AV, dan E ditemukan beberapa hal terkait dengan pendapatan masyarakat di masa pandemic Covid19. Menurut peserta pelatihan AL menjelaskan bahwa pendapatannya sebelum mengikuti pelatihan menjahit dirasa kurang untuk memenuhi kebutuhan sehari-harinya. Hal ini karena sulitnya mencari pekerjaan sehingga AL mengalami pengangguran, akan tetapi setelah mengetahui adanya kursus dan pelatihan menjahit ini AL mengikuti kursus sampai sekarang dengan lamanya kurang labih 2 bulan tetapi AL sudah bisa menjahit dengan rapi karena tutor yang selalu mengajarkan AL dengan melaksanakan praktik dibanding materi, selain pelatihan menjahit di LKP Mekar Sari juga mengajarkan peserta didik dalam menumbuhkan karakter wirausaha melalui materi, walaupun karakter tumbuh pada diri sendiri tetapi tutor menerapkan dasar dari penumbuhan karakter itu sendiri.

Menurut penjelasan dari AS, ia mengikuti pelatihan menjahit ini karena AS sudah mempunyai konveksi di rumahnya akan tetapi kurang dalam pendapatan, tujuan AS mengikuti kursus ini karena ia ingin meningkatkan kembali konveksinya dan meningkatkan keterampilannya dalam menjahit, sehingga ia dapat meningkatkan usahanya denganb menambah beberapa model baju di konveksinya. Untuk penumbuhan karakter pada AS sudah bagus karena pada saat ini terutama di masa Pandemic Covid-19 ia dapat mencipakan ide dan model baru di perusahaannya sehingga omset dari usahanya itu meningkat.

Menurut peserta didik AV, ia telah mengikuti pelatihan menjahit ini selama 2 bulan dengan tujuan ia ingin membuka usaha mandiri, karena ketika ia melamar pekerjaan termasuk ke pabrik garmen ia selalu di tolak dengan alasan karena ia bertato. Maka dari itu tutor membantu ia dalam meningkatkan karakter wirausahanya agar AV mampu dan mengerti ketika AV membuka usaha mandiri, AV mengatakan bahwa ia ingin secepatnya mempunyai konveksi yang ternyata keinginan ini sebagian dari cita-cita AV semenjak lulus SMA.

Menurut peserta didik E, menjelaskan bahwa ia ingin membantu orang tuanya dalam mendapatkan penghasilan untuk kebutuhan sehari-hari, akan tetapi ia baru saja lulus sekolah sehingga $\mathrm{E}$ belum mendapatkan pengalaman apapun, pada akhirnya $\mathrm{E}$ mengikuti pelatihan menjahit di LKP Mekar sari karena LKP Mekar Sari setiap tahun selalu ada penyaluran peserta didik ke pabirik garmen yang tempatnya berada di belakang LKP Mekar Sari, lamanya E mengikuti kursus yaitu 2 bulan dan ia sempat di salurkan ke pabrik garmen akan tetapi $\mathrm{E}$ masih kurang menguasai dalam menjahit, maka dari itu $\mathrm{E}$ menyelesaikan kursus menjahit sampai lulus di level 1. E pun menjelaskan bahwa selama ia menunggu kursusnya selesai ia membuat masker kain di rumahnya untuk di jual melalui media sosial dan sedikit demi sedikit ia mendapakan pendapatan dari usaha maskernya. Karakter wirausaha E sudah cukup bagus karena ia mampu dan berani membuat usaha masker dan di jual di media sosial dengan pendapatan yang cukup banyak.

\section{Implikasi dari kursus dan pelatihan menjahit dan proses penumbuhan karakter wirausaha pada peserta didik di Masa pandemic Covid-19}

Berdasarkan hasil wawancara dengan peserta didik Al dari adanya pelatihan ini sangat bermanfaat untuk meningkatkan keterampilan dan membekali wawasan peserta didik. Dengan keterampilan yang didapat dari pelatihan menjahit di masa pandemic Covid-19 
membuat peserta lebih mandiri, peserta didik bisa bekerja sesuai dengan keahlian yang telah dimiliki bahkan setelah lulus dari pelatihan ini peserta didik mendapatkan sertifikat. Al sendiri merasakan manfaatnya setelah 2 bulan mengikuti pelatihan ini yaitu ia merasa sudah mempunyai keahlian dalam satu bidang yaitu menjahit, maka Al terkadang membantu konveksi AV untuk mengisi waktu kosong ketika hari libur, dan juga mendapatkan sebagian upah dari pekerjaannya di konveksi AV.

Menurut AS setelah mengikuti pelatihan ini ia sangat merasakan dampaknya, karena dengan meningkatnya omset yang didapat di konveksinya ia juga akan terus menambah ide baru untuk membuat desain yang baru dan lebih menarik untuk meningkatkan perhatian konsumen. AS merasa lebih bersemangat untuk menjalankan usahanya karena dengan kepercayaan diri yang kuat dan suport dari orang tua ia jadi semakin lebih ingin mengembangkan usahanya. Selain itu AS juga semakin mengerti dengan tumbuhnya karakter berwirausaha pada dirinya ia semakin ingin membuktikan bahwa ia mampu dan dapat berwirausaha dengan jujur agar konsumen merasa puas dengan hasilnya.

Hasil wawancara dari AV setelah mengikuti pelatihan menjahit ini ia juga sangat merasakan manfaatnya yang cukup cepat, karena setelah 2 bulan mengikuti pelatihan menjahit ia juga telah membuka konveksi baju seragam anak sekolah yang dibantu oleh orang tuanya sehingga AV mempunyai 5 orang pegawai di konveksinya. Konveksi AV sudah mulai bermitra dengan beberapa sekolah untuk menjadi langganan membuat seragam anak di konveksinya. Akan tetapi semenjak adanya pandemic Covid-19 para sekolah yang sudah bermitra ataupun yang belum bermitra hampir tidak ada yang menghubungi konveksi AV karena pada saat pandemic saat ini sekolah sudah tidak melakukan pembelajaran secara tatap muka melainkan melalui daring (dalam jaringan), maka dari itu AV dan orang tuanya menambah ide baru agar usaha konveksinya tidak turun.

Menurut E, hasil yang didapat setelah mengikuti pelatihan ini, dengan ia membuat masker kain yang di jual melalui sosial media ia mampu untuk membantu orang tuanya dalam menghasilkan pendapatan di masa pandemic ini. E merasa ia telah mendapatkan satu keahlian pada dirinya yang sangat bermanfaat untuk orang banyak. Dengan berjalannya usaha mandiri yang dilakukan E yaitu membuat masker E juga mulai membuka ide baru yaitu membuat kerudung yang dijual melalui media sosial juga, dari sini E sadar bahwa ia mampu dan bisa melalui masa naik dan turunnya berwirausaha.

\section{Pembahasan}

Pelaksanaan pelatihan menjahit dan meningkatkan penumbuhan karakter wirausaha pada peserta didik di LKP Mekar Sari di masa pandemic Covid-19

Pelaksanaan pelatihan menjahit di masa pandemic Covid-19 awalnya sempat terhambat karena mengalami pemberhentian pelatihan selama 3 bulan, akan tetapi setelah semuanya membaik dilaksanakan kembali pelatihan dengan normal tetap dengan protokol kesehatan, peserta didik dan tutor selalu mencuci tangan sebelum masuk LKP dan selalu memakai masker sekalipun sedang melaksanakan pelatihan. Pelatihan menjahit di LKP Mekar Sari tetap melakukan tatap muka dan tetap melaksanakan praktik disetiap pertemuannya. Dalam pelaksanaan pelatihan tutor juga tidak banyak mengalami kesulitan dalam melakukan pembelajaran atau praktik karena sebagian besar peserta didik dari kelas reguler sudah mempunyai dasar pengetahuan dan keahlian dalam menjahit. Pada kelas reguler terdapat perbedaan tujuan dalam berwirausaha di setiap peseta didiknya, akan tetapi sama-sama untuk 
mensejahterakan keluarganya. maka dari itu setiap satu bulan sekali sampai dua kali tutor mengadakan pelatihan dalam bentuk materi dengan tema untuk menumbuhkan karakter wirausaha dalam mengembangkan keterampilan menjahit. Dengan harapan peserta didik mampu dan berani ketika suatu saat akan membuka usaha mandiri. Karakter adalah sifat atau tingkah laku seseorang, maka dari itu dapat diartikan bahwa karakter wirausaha yaitu sifat atau tingkah laku yang khas yang dapat membedakan dari orang lain (Mayndarto, 2017).

\section{Implikasi dari kursus dan pelatihan menjahit dan proses penumbuhan karakter wirausaha pada peserta didik di Masa pandemic Covid-19}

Bagi peserta didik, dengan adanya kursus dan pelatihan menjahit ini terutama masih tetap dilaksanakannya pelatihan meskipun dalam keadaan pandemic, peserta didik menyatakan bahwa banyak manfaat dan ilmu yang telah didapat setelah mengikuti pelaksanaan pelatihan menjahit ini, mulai dari meningkatnya keterampilan membuat peserta didik menjadi lebih mandiri untuk menciptakan model-model dan ide baru, selain itu peserta didik juga bisa bekerja sesuai dnegan keahlian yang telah dimiliki bahkan setelah mengikuti pelatihan ini peserta didik akan mendapatkan sertifikat untuk menjadi bukti ketika telah mempunyai usaha baru agar menjadi usaha mandiri yang terpercaya dan menjadi kepuasan bagi konsumen itu sendiri.

Dengan keahlian tersebut mereka bisa bekerja berdampingan langsung dengan masyarakat. Hasil dari pelatihan ini, jika peserta didik bersungguh-sungguh dalam mempelajari sesuatu hal maka akan mendapatkan hasil yang sesuai dengan yang diharapkan. Dapat diimplementasikan dimasyarakat, bahkan dari pelatihan menjahit ini menjadikan suatu keahlian yang dapat menjadi mata pencaharian untuk mensejahterakan peserta didik dan keluarganya. Setelah mengikuti pelatihan tersebut pada dasarnya sebagian besar dari peserta didik yang mengikutinya bukan karena tidak mempunyai pekerjaan, akan tetapi ingin mengikuti pelatihan menjahit ini yaitu untuk menambah wawasan, dan meningkatkan keterampilan. Keterampilan hidup (life skills) ada pada pendidikan non-formal, diantaranya berkaitan dengan keterampilan fisik, keterampilan spiritual, keterampilan mental, keterampilan emosiaonal, kejujuran dan keterampilan menghadapi kesulitan ketika sudah mempunyai usaha mandiri. Kecakapan hidup juga sangat penting untuk dikembangkan yaitu dengan bagaimana seseorang dapat menggunakan semua nilai-nilai positif dan kompetensi yang dimiliki secara maksimal untuk diimplementasikan dalam mempertahankan hidup sehari-hari. (Mislaini, 2017)

\section{KESIMPULAN}

Berdasarkan hasil penelitian kepada peserta didik terhadap Implikasi pelatihan menjahit dalam menumbuhkan karakter wirausaha peserta didik di masa pandemic COVID-19 dapat disimpulkan bahwa :

\section{Pelaksanaan pelatihan menjahit dan meningkatkan penumbuhan karakter wirausaha pada peserta didik di LKP Mekar Sari di masa pandemic Covid-19}

Walaupun terjadinya pandemic Covid-19 dimana segala aktivitas serba terbatas bahkan sempat mengalami pemberhentian pelaksanaan pelatihan selama 3 bulan, akan tetapi setelah dilaksanakannya kembali pelatihan ini tidak menjadikan hambatan untuk terus berlatih. Peserta didik dan tutor tetap melaksanakan pelatihan secara tatap muka seperti biasanya namun tetap dalam pengawasan protokol kesehatan. 
2. Implikasi dari kursus dan pelatihan menjahit dan proses penumbuhan karakter wirausaha pada peserta didik di Masa pandemic Covid-19

Dengan sistem pelatihan tersebut, peserta dituntut untuk lebih mandiri baik dari proses pelatihan maupun setelah selesai pelatihan. Bahkan setelah berjalannya kembali pelatihan menjahit ini semenjak 3 bulan berhenti, sebagian dari peserta didik sudah mempunyai usaha mandiri mulai dari membuka konveksi, permak pakaian, hingga membuat masker dan kerudung hasil jahitan sendiri membuat peserta didik merasakan dampak baik dari pelatihan ini. Sehingga peserta didik dapat menambah pendapatan untuk membantu orang tuanya dalam memenuhi kebutuhan sehari-hari. Selain itu peserta didik juga telah menumbuhkan karakter berwirausaha pada dirinya, walaupun usahanya berbeda-beda akan tetapi peserta didik di LKP Mekar sari lebih mengutamakan kejujuran dan membuat ide-ide baru dalam usahanya agar konsumen merasa puas dengan hasil usahanya.

\section{DAFTAR PUSTAKA}

Agustiyanti. (2019, November Selasa). Peringkat Daya Saing Indonesia Turun, Makin Tertinggal dari Malaysia. Dipetik Januari 20, 2021, dari Katadata.co.id: https://www.google.co.id/amp/s/katadata.co.id/amp/agustiyanti/finansial/5e9a4e606bfc0/perin gkat-daya-saing-indonesia-turun-makin-tertinggal-dari-malaysia

Ahmad Husein, J. S. (2017). Pembelajaran Kursus Menjahit di Lembaga Kursus dan Pelatihan (LKP) Nissan Fortuna Kabupaten Kudus. Jurnal Eksistensi Pendidikan Luar Sekolah (E-Plus), Volume 2 Nomor 1, 37. Diambil kembali dari Jurnal Eksistensi Pendidikan Luar Sekolah (EPlus).

Dewi, K. N. (2018, April Rabu). Uji Kompetensi Lembaga Kursus \& Pelatihan (LKP) Di Kabupaten Pasuruan Tahun 2018. Dipetik Februari 2021, 2021, dari dispendik.pasuruankab.go.id: https://dispendik.pasuruankab.go.id/berita-915-uji-kompetensi-lembaga-kursus-pelatihan-lkpdi-kabupaten-pasuruan-tahun-2018.html

Idhom, A. M. (2020, Juni Senin). Update Corona 8 Juni 2020 di Indonesia \& Dunia. Dipetik Maret 18, 2021, dari Tirto.id: https://tirto.id/update-corona-8-juni-2020-di-indonesia-dunia-databaru-hari-ini-fF5T

Joesyiana, K. (2018). Pengaruh Word Of Mouth Terhadap Keputusan Pembelian Konsumen pada Media Online Shop Shopee di Pekan Baru. Jurnal Valuta, Volume 4 Nomor 1, 78.

Mayndarto, D. R. (2017). Pembangunan Karakter Wirausaha Mahasiswa Melalui Peningkatan Kualitas Pendidikan kewirausahaan. Jurnal Ekonomi, Volume 1 Nomor 3, 350.

Mislaini. (2017). Pendidikandan BimbinganKecakapan Hidup (Life Skill) Peserta Didik. Jurnal Tabawiyah, Volume 1 Nomor 2, 151.

Sugiyono, P. D. (2018). Metode Penelitian Kuantitatif, Kualitatif, dan R\&D. Bandung: CV. Alfabeta. 